\title{
Receptorok a gasztroenterológiában: történeti áttekintés
}

\author{
Buzás György Miklós dr. \\ Ferencvárosi Egészségügyi Szolgáltató Közhasznú Nonprofit Kft., Gasztroenterológia, Budapest
}

Az élő szervezetekben az élettani folyamatokat a sejthártyán elhelyezkedő jelátvivők - receptorok - közvetítik. A jelátvivők tanulmányozása több mint 125 éve foglalkoztatja a biológiai tudományok múvelőit [1]. A PubMed-ben a „receptor” keresőszónál 1209240 közlemény szerepel: az első 1905-ből származik (http://www.pubmed. com, 2018. 11. 27.), jelezve a hatalmas érdeklődést, amely a témát övezte. A dolgozat célja a receptorok történetének áttekintése.

\section{A receptor fogalmának kialakulása}

A 'receptor' kifejezés a XIX-XX. század fordulóján alakult ki. Eredete a latin recipio = kapni szó, amely előbb a francia nyelvből került át [2]. „Előfutára” a ceptor kifejezés, amely a latin ceptus = elvenni terminusból származik, és Charles Scott Sherrington (1857-1952) fiziológus, filozófus és költő vezette be (Nobel-díj: 1932) [3]. Neurofiziológiai tanulmányában a ceptor olyan struktúra, amely megfelelő inger hatására kémiai folyamatot indít el [1]. Ilyen anyag volt a Jokichi Takamine (1854-1922) által 1901-ben felfedezett adrenalin és az 1828 óta ismert nikotin $[3,4]$. 1878-ban John Newport Langley (1852-1925) kutyakísérletek során észlelte, hogy az atropin és a pilokarpin a nyálmirigyekben vegyületekhez, míg a nikotin és a kuráré „kontraktilis anyaghoz” kötődik: az előbbieket „receptí anyagok” nevezte $[1,5]$. A receptív anyagok kiváltotta válasz mennyiségi elemzését Langley diákja, Archibald Vivian Hill (1886-1977) londoni biofizikus és fiziológus végezte el, aki matematikai képletbe foglalta a békahasizom nikotin kiváltotta összehúzódásának időbeli lezajlását: ez volt az első dózis-hatás görbe - izomélettani kutatásaiért 1922-ben Nobel-díjat kapott.

A 'receptor' kifejezést először Paul Ehrlich (18541915 ) javasolta az immunológiában olyan biológiailag aktív molekulákra, amelyek a sejtek felületén helyezkednek el. 1897-ben feltételezte, hogy a baktériumokon és a sejteken elhelyezkedő „oldalláncok” kapcsolódnak egymáshoz és semlegesítik a toxinokat: ezeket előbb amboceptornak, majd receptornak nevezte (Nobel-dij: 1908) [6].
A receptorokra ható vegyületek agonista és antagonista jellegét Alfred Joseph Clark (1885-1941) edinburghi farmakológus mutatta ki 1926-ban: az acetil-kolin és az atropin szívizomra és békahasizomra gyakorolt hatását tanulmányozta. Ö mutatta ki a koncentráció-hatás görbe jobbra tolódását $[4,7]$. Munkáját a horvát születésü, Budapesten is tanult Heinz Otto Schild (1908-1984) tökéletesítette, kidolgozva a ligand-receptor kompetitív, nonkompetitív, kooperatív és irreverzíbilis kötődési modelljeit [4]. A receptorkutatás számos új módszerrel bővült (radioaktív és nem radioaktív meghatározások, fluoreszcenciapolarizáció, felületi plazmonrezonancia, rekombináns receptorok vizsgálata) [8].

Az Orvosi Hetilapban 1964 és 2018 között 224 közlemény jelent meg a receptorokról: (http://www.pubmed. com, 2018. 11. 09.): ezek foglakoznak hormonreceptorokkal [9], gyulladásos bélbetegségek molekuláris aspektusaival [10], neuroendokrin tumorok kezelésével [11], a Toll-szerü receptorokkal [12], a tirozin-kináz-receptorgátlókkal [13] és a proteoglikánreceptorokkal [14]; mindegyiknek van gasztroenterológiai vonatkozása.

\section{A gastrointestinalis receptorok története}

\section{Acetil-kolin-receptorok}

A strasbourgi német farmakológus, Otto Loewi (18731961) 1921-ben mutatta ki, hogy a vagusvégződésekből olyan anyag szabadul ki, amely csökkenti a szívritmust. 1929-ben Sir Henry Hallett Dale (1875-1968) brit fiziológus azonosította az acetil-kolint: ez volt az első neurotranszmitter. Loewi és Dale 1936-ban kapott Nobeldíjat [3]. Az acetil-kolin nikotin típusú receptorát 1963ban írták le: a neurotranszmisszióban fontos, és nemcsak receptorként, hanem ioncsatornaként is múködik. A muszkarint a légyölő galócából (Amanita muscaria) vonta ki a dorpati egyetemen (ma: Tartu, Észtország) a farmakológia egyik megalapítója, Johann Ernst Oswald Schmiedeberg (1838-1921). Az M-receptor létét már 1908-ban feltételezte Walther Straub (1874-1944) lipcsei farmakológus, kimutatva atropin- és muszkarinantagonista hatását. Struktúráját 1957-ben röntgendiffrakci- 
óval állapították meg [1], s máig 5 típusát $\left(\mathrm{M}_{1-5}\right)$ különböztetik meg. A gyomor fali sejtjein $M_{1}$ típusú receptorok helyezkednek el, míg az izomsejteken, ereken és nyálmirigyekben $\mathrm{M}_{3}$-receptorok találhatók.

$\mathrm{Az} \mathrm{M}_{\mathrm{l}-5}$-receptorok $\mathrm{G}$-proteinek által fejtik ki hatásukat, amelyek már a baktériumokban is jelen vannak, és végigkövették a fajfejlődést. Strukturálisan 7 transzmembrán részból álló heterodimerek, és guanint tartalmaznak. A G-protein-családot 1976-ban Alfred G. Gilman (1941-2015) és Martin Rodbell (1925-1998) fedezte fel; 1994-ben Nobel-díjat kaptak. Ma 18-féle Gprotein ismert, génjeik a humán genom egyik legnagyobb családját alkotják.

Az $M_{1}$-receptor típusos antagonistája az ókorból ismert atropin. Először 1540-ben alkalmazta görcsoldóként a zürichi Conrad Gessner (1516-1565); 1872-ben Rudolf Peter Heinrich Heidenhain (1834-1897) mutatta ki, hogy csökkenti a nyálelválasztást, hidrogén-klorid $(\mathrm{HCl})$-gátló hatását pedig 1896-ban Usakov szentpétervári doktorandusz mutatta ki $[3,15]$. A hiperaciditás és a peptikus fekély kezelésére széleskörúen használták, de mellékhatásai miatt számos analógot fejlesztettek ki (1956: propantelin-bromid, 1959: oxifenciklamin, 1960: izopropamid-jodid, 1961: poldin metil-szulfát, 1962: glikopirrónium-bromid). Mivel az $\mathrm{M}_{1}$-receptorok a simaizomsejteken és ereken is megtalálhatók, a kutatások szelektív vegyületek keresésére irányultak, így 1977 ben a pirenzepint, 1985-ben a telenzepint szintetizálták, de a $\mathrm{H}_{2}$-receptor-blokkolókkal nem tudták felvenni a versenyt $[15,16]$.

\section{Hisztaminreceptorok}

A hisztamint Adolf Windaus (1876-1959) szintetizálta 1907-ben [3]. Henry Hallett Dale jellemezte fóbb hatásait, de a Nobel-díjat 1936-ban az idegrendszeri jelátvi- tel felfedezéséért kapta. Az első antihisztamint 1941-ben szintetizálták francia vegyészek, de azok nemszelektívek és toxikusak voltak. Angol és amerikai cégek állították elő a difenhidramint (1943), feniramint (1951), ciproheptadint (1965): ezek nem befolyásolták a HCl-termelést, hanem centrális szedatív hatásuk volt, ezért feltételezték, hogy hatásukat hisztamin $H_{1}$-receptorok közvetítik [16]. 1938-ban Hetényi Géza (1894-1959) próbálkozott hisztamindeszenzibilizációs kezeléssel, mivel kutyában a hisztamin emelkedő adagban gátolta az atofánfekélyek keletkezését. Fekélybetegekben az őszi-tavaszi deszenszibilizációs kúrák 7 éves követés után az esetek 85\%-ában megelőzték a recidívákat: ezek is a receptorokra hatottak, a professzor tudta nélkül [17].

Az első $\mathrm{H}_{1}$-receptor-antagonistát 1933-ban fedezte fel Daniel Bovet (1907-1992) svájci-olasz farmakológus, kimutatva, hogy a piperoxan gátolja a hisztamin indukálta hörgőgörcsöt tengerimalacban (orvosi Nobel-díj: 1957) $[3,16]$.

Angliában Raymond Perry Ahlquist (1914-1983) azonosította az alfa- és béta-adrenerg receptorokat 1948-ban, és ennek nyomán Schild feltételezte, hogy a hisztamin is különböző receptorokon fejti ki hatásait. Sir James Whyte Black (1924-2010) skót kutató 1958-ban kezdte kutatásait, és klasszikussá vált kísérleti modelleken sikerült elkülönítenie a hisztamin hatásait. A hisztamin $\mathrm{H}_{2}$-receptorokról szóló dolgozatot 1972-ben közölték, amely az egyik legtöbbet idézett munka lett a szakirodalomban (Nobel-díj: 1998) [18]. A H2-receptor-antagonisták történetét az 1 . táblázatban vázoljuk $[15,16,19,20]$. A H ${ }_{2}$-receptor-blokkolók háttérbe szorították az antacid és antikolinerg szereket: uralmuk két évtizedig tartott, amikor a protonpumpagátlók és a $\mathrm{He}$ licobacter pylori-eradikáció átvette helyüket. Kétséges, hogy az új generációs protonpumpagátlók és a kálium-

1. táblázat |A hisztamin $\mathrm{H}_{2}$-receptor-blokkolók története $[15,16,19,20]$

\begin{tabular}{|c|c|c|c|c|}
\hline Év & Vegyület & Kémiai szerkezet & Gyógyszer & Megjegyzés \\
\hline 1970 & Burimamid & Imidazolgyúrü & Az első kompetitiv $\mathrm{H}_{2}$-receptor-blokkoló & Rossz felszívódás \\
\hline 1970 & Metiamid & Imidazolgyűrü & Jól felszívódó, szelektív $\mathrm{H}_{2}$-receptor-antagonista & Agranulocytosis miatt visszavonták \\
\hline 1972 & Cimetidin* & Imidazolgyűrü & $\begin{array}{l}\text { Az első, Tagamet }{ }^{\circledR} \text { néven gyógyszertári } \\
\text { forgalomba kerülő } \mathrm{H}_{2} \text {-receptor-antagonista }\end{array}$ & $\begin{array}{l}\text { 1983-ban, a világon elöször, forgalma } \\
\text { meghaladta az évi } 1 \text { milliárd dollárt }\end{array}$ \\
\hline 1975 & Oxmetidin & Guanidin-izocitozin & A cimetidinnél erősebb hatású & Nem kerül forgalomba \\
\hline 1982 & Ranitidin* & Furángyürü & Zantac $^{\circledR}$ néven került forgalomba & 1986-ban évi 2 milliárd dolláros forgalma volt \\
\hline 1982 & Famotidin * & Guanidiltiazol & Prevacid® néven 1985-ban került forgalomba & $\begin{array}{l}\text { Hatása erősebb és hosszabb időtartamú, mint a } \\
\text { cimetidiné/ranitidiné }\end{array}$ \\
\hline 1982 & Nizatidin & Tiazolgyürü & Axid $^{\circledR}$ néven került forgalomba & $\begin{array}{l}\text { A ranitidin és a famotidin mellett háttérbe } \\
\text { szorult }\end{array}$ \\
\hline 1991 & Ebrotidin & Furángyürü & A ranitidinnel azonos hatású + cytoprotectiv & $\begin{array}{l}\text { A nyombélfekély akut kezelésében jobb a } \\
\text { ranitidinnél, fenntartó kezelésben azonos hatású }\end{array}$ \\
\hline 1992 & Lafutidin & $\begin{array}{l}\text { Furfuril-szulfinil- } \\
\text { piperidinil-aceta- } \\
\text { mid-származék }\end{array}$ & $\begin{array}{l}\text { A lanzoprazollal egyenértékű a fekély gyógyítá- } \\
\text { sában és a Helicobacter pylori-eradikációban. } \\
\text { Refluxbetegségben gyengébb }\end{array}$ & Nem került forgalomba \\
\hline
\end{tabular}

*Magyarországon a cimetidin (Chinoin), a ranitidin, a famotidin (Richter) került forgalomba, eredeti szintéziseljárások alkalmazásával. 
csatorna-blokkolók mellett lesz-e további fejlesztés a $\mathrm{H}_{2}$ receptor-blokkolók területén.

A $\mathrm{H}_{2}$-receptor szerkezetét röntgendiffrakciós vizsgálattal 1984-ban tisztázták: hatását G-proteinhez kapcsolódva fejti ki [21].

A $\mathrm{H}_{2}$-receptor-blokkolók kutatásával Pécsett Jávor Tibor (1926-2007) és Mózsik Gyula foglalkozott, több évtizeden át klinikai és farmakológiai vizsgálatokat végezve; tevékenységüket számos hazai és nemzetközi publikáció jelzi [22].

A hisztamin $\mathrm{H}_{3}$-receptort 1983-ban írták le a központi idegrendszerben: szerepe a hisztaminszintézis szabályozása. A gyomorban 1991-ben írták le. Önszabályozó szerepe a carbakol- és pentagasztrinstimulált $\mathrm{HCl}$-szekréció gátlása révén érvényesül. A receptor egy 70 kilodalton (kDa) tömegú protein, amelyet kísérleti gyomordaganat sejtjein sikerült izolálni. $\mathrm{A} \mathrm{H}_{3}$-receptort az $\mathrm{N}$-metil-hisztamin stimulálja, a tioperamid gátolja, a ranitidin viszont nem hat rá. $\mathrm{A} \mathrm{H}_{3}$-receptor is a G-proteinhez kapcsolt szupercsaládhoz tartozik. Agonistája a pitolizant, idegrendszeri serkentő hatással rendelkezik, és narcolepsiában, Parkinson-betegségben, alvási apnoéban használják. Emésztőszervi alkalmazása nincs [23].

A receptorcsalád utolsói tagja a hisztamin $\mathrm{H}_{4}$-receptor: 200l-ben azonosították. A hisztamin eozinofil sejtekre gyakorolt kemoattraktív hatása már 1975 óta ismert volt. $\mathrm{A} \mathrm{H}_{4}$-receptort mastocytákon, vékony- és vastagbél-epithelsejteken, lépben és csontvelőben sikerült lokalizálni; G-proteinhez kapcsolt fehérje. Agonistái közül a toreforant került alkalmazásra a rheumatoid arthritis, asztma, psoriasis és pruritus kezelésében. Reményeket füznek ahhoz, hogy újabb $\mathrm{H}_{4}$-receptor-antagonisták hatásosak lesznek az eozinofil mediálta kórképek (oesophagitis, gastroenteritis) kezelésében [24].

\section{Dopaminreceptorok}

A dopamint 1910-ben szintetizálták a londoni Wellcome-laboratóriumban, és 1957-ben mutatták ki az idegrendszerben, mellékvesében és szimpatikus idegvégződésekben. A vegyület neurotranszmitter jellegét 1958ben igazolták Arvid Carlsson (1923-2018) és munkatár- sai a lundi egyetemen (2000: élettani Nobel-díj). A dopaminreceptort 1976-ban fedezték fel, és azóta 5 altípusát különítették el; 2 családba oszthatók: a $D_{1}-D_{5}$-receptorok a $\mathrm{D}_{1}$-családba tartoznak és G-proteinhez kapcsoltak, a $\mathrm{D}_{2-4}$-receptorok pedig a $\mathrm{D}_{2}$-családba sorolandók, és önszabályozó, illetve posztszinaptikus jellegüek. A dopaminerg jelátvitelnek elsősorban az idegrendszerben van fontos szerepe (Parkinson-kór, skizofrénia, alkohol- és drogfüggés, Gilles de la Tourette- és figyelemhiányos hiperaktivitás szindróma). Szabó Sándor Bostonban az 1980-as években mutatta ki, hogy a $\mathrm{D}_{2}$-receptorok részt vesznek a ciszteamin indukálta kísérleti nyombélfekély patogenezisében [25], majd 2015ben igazolta, hogy kísérleti colitisben a $\mathrm{D}_{2}$-receptor-agonisták csökkentik a vascularis endothelialis növekedési faktor (vascular endothelial growth factor - VEGF) mediálta vascularis permeabilitást és ezáltal a nyálkahártya gyulladását [26]. Az itopridet 1994-ben fejlesztették ki; dopamin $\left(\mathrm{D}_{2}\right)$-receptor-antagonista, és acetil-kolin-észteráz-gátló hatása van [16].

\section{Szerotoninreceptorok}

A szerotonint 1948-ban fedezték fel a clevelandi klinikán mint keringó vasoconstrictor anyagot [27]. Egy évvel később kiderült, hogy szerkezete 5-hidroxi-triptamin (5HT); 1951-ben szintetizálták [16]. Kezdetben a thrombocytákban és az enterokromaffin sejtekben, majd 1953ban az idegrendszerben mutatták ki jelenlétét. A keringő szerotonin 95\%-a a bél enterokromaffin sejtjeiből származik. A szerotoninreceptorokat 1957-ben azonosította John Henry Gaddum (1900-1965) és munkatársa; kezdetben D-típusú, musculotrop és M-típusú, neurotrop receptorokat írtak le: az utóbbiakat később átkeresztelték 5-HT-receptoroknak [28]. A kutatások során 15 receptort azonosítottak a központi idegrendszerben és a gyomor-bél rendszer epithel- és izomsejtjein: ezek eredményeképpen számos gyógyszer került alkalmazásra a depresszió, a skizofrénia, a motilitászavarok és a hányinger kezelésére. Az 5-HT-receptorok is G-proteinhez kapcsolódva múködnek. A 2. táblázatban az emésztő-

2. táblázat |Az 5-hidroxi-triptamin-receptorok, -agonisták és -antagonisták története [15, 16, 29]

\begin{tabular}{|c|c|c|c|}
\hline Év & Vegyület & Hatásmechanizmus & Indikációk \\
\hline 1957 & Metoklopramid & $\begin{array}{l}\text { 5- } \mathrm{HT}_{4} \text {-agonista, } 5 \text { - } \mathrm{HT}_{3} \text {-antagonista, } \mathrm{D}_{2} \text {-receptor-anta- } \\
\text { gonista }\end{array}$ & Prokinetikum, hányinger kezelése \\
\hline 1974 & Domperidon & $\mathrm{D}_{2}$-receptor-antagonista, 5 - $\mathrm{HT}_{3}$-antagonista & $\begin{array}{l}\text { Prokinetikum, hányinger, gastroparesis, IBS, funkcionális } \\
\text { diszpepszia kezelése }\end{array}$ \\
\hline 1988 & Cizaprid* & $\begin{array}{l}\text { 5- } \mathrm{HT}_{4} \text {-agonista, } \mathrm{D}_{2} \text {-antagonista, } 5 \text { - } \mathrm{HT}_{2 \mathrm{~A}, 2 \mathrm{~B}} \text {-antagonis- } \\
\text { ta, alfa-1-adrenoceptor-agonista }\end{array}$ & $\begin{array}{l}\text { Funkcionális diszpepszia, refluxbetegség, gastroparesis, } \\
\text { IBS kezelése }\end{array}$ \\
\hline 1990 & Ondanzetron & 5- $\mathrm{HT}_{3}$-receptor-antagonista & Posztoperatív és kemoterápia utáni hányinger kezelése \\
\hline 1999 & Prukaloprid & 5- $\mathrm{HT}_{4}$-receptor-agonista & Székrekedés kezelése \\
\hline
\end{tabular}

*Szívritmuszavarok miatt 2004-ben visszavonták.

5-HT = 5-hidroxi-triptamin; IBS = irritábilisbél-szindróma 
szervi farmakológiában alkalmazásra lelt gyógyszerek fejlesztését mutatjuk be: mindegyikből több analógot fejlesztették ki [15, 16, 29].

\section{Hormonális receptorok}

A gastrointestinalis endokrinológia a XX. század elején keletkezett, amikor az első hormonokat - szekretin és gasztrin - azonosították [30, 31]. A „klasszikus” hormonokkal szemben (szteroidok, tiroxin, tesztoszteron, ösztrogének) az emésztőszervi hormonok receptorai nem a sejtmagon vagy citoplazmában helyezkednek el, hanem a fentiekhez hasonlóan a sejthártyán. A kutatások iránya és az ismeretek bővülése a hormon felfedezése után a sejtes eredet, a hormont és receptorát kódoló gén azonosítása felé haladt (3. táblázat) [30-35]. Amint az endokrin sejtek és receptorok szétszórtan helyezkednek el az emésztőtraktusban, a receptorokat kódoló gének is különböző kromoszómákon találhatók: ennek biológiai oka/jelentése nem ismert. A gastrointestinalis receptorok ligandjai a G-protein-család tagjaihoz kötődve fejtik ki hatásukat. A hormonkutatásba fektetett hatalmas szellemi és anyagi erőforrások aránylag kevés gyakorlati alkalmazást nyertek a gasztroenterológiában. Új szemléletet hozott az ún. izotópos teranosztikai módszer; a kifejezés a terápia + diagnosztika összevonásából ered: az izotóppal jelzett szomatosztatinanalógoknak $\left({ }^{128} \mathrm{I}\right.$, ${ }^{131}$ I-oktreotid, ${ }^{111}$ In-pentetreotid) - amellett, hogy jelzik a neuroendokrin tumorok lokalizációját - terápiás hatásuk is van, az újabb eredmények szerint javítják a túlélést [32]. Tulassay Zsolt és mtsai a szomatosztatin terén értek el nemzetközileg is számon tartott eredményeket [34].

\section{Tirozin-kináz-receptorok}

A tirozint Justus von Liebig (1803-1873) német kémikus azonosította 1846-ban mint a pancreas emésztéstermékét. Szintézisét Emil Erlenmeyer (1825-1909) végezte el 1883-ban, szerkezetét Hermann Emil Louis Fischer (1852-1919) fejtette meg [36]. A tirozin részben esszenciális aminosav, beépül a polipeptidláncokba, és az adrenalin, noradrenalin, dopamin és melanin prekurzor vegyülete. A kinázok foszfátcsoport áthelyezését katalizálják nagy energiájú donormolekulákról (adenozin-trifoszfát [adenosine triphosphate - ATP]) specifikus struktúrákra: ez a foszforilációnak nevezett alapvető biokémiai folyamat. A tirozin-kinázok a jelátvitelben, sejtdifferenciálódásban, immunvédekezésben és onkogenezisben játszanak szerepet: az emberi szervezetben több mint 500-fajta kináz található [37]. Angol nyelvterületen a nevük receptor-tirozin-kináz.

A sejtekhez az információ az extracellularis tér felől kémiai vagy elektromos úton érkezik, és a sejthártyán át a génállományig bonyolult jelátviteli úton halad. A foszforiláció kutatása az 1950-es években kezdődött, és a kutatásoknak lendületet adott az Earl Wilbur Sutherland (1915-1974) által felfedezett adenozin-monofoszfát (AMP) és AMP-kináz (Nobel-díj: 1971) [3, 15, 37]. A tirozin-kinázok az ATP-ról egy foszfátcsoportot helyeznek fehérjék aminoterminális részére, és ezzel módosítják a fehérjemolekulák funkcióját. A tirozin-kináz-receptorok transzmembrán struktúrák: a sejthártyán kívül eső rész receptor, amely a fehérjék egyes aminosavszekvenciáival reagál; belső része enzim, amely foszforilálódik, és ezáltal egyes intracellularis fehérjék szerkezete és

3. táblázat | Egyes gastrointestinalis hormonreceptorok története [9, 15, 16, 30-35]

\begin{tabular}{|c|c|c|c|c|c|}
\hline Év & Hormon & Sejtes eredet & Receptorlokalizáció & $\begin{array}{l}\text { Receptorgén- } \\
\text { lokalizáció }\end{array}$ & Diagnosztikai és terápiás alkalmazások \\
\hline 1902 & Szekretin & $\begin{array}{l}\text { Duodenalis S-sejt } \\
(1983)\end{array}$ & Pancreasacinus-sejt & 11. kromoszóma & $\begin{array}{l}\text { Szekretinteszt pancreasbetegségekben } \\
\text { (1942); fekélyellenes kezelés (1966); } \\
\text { gastrinoma diagnózisa (1972) }\end{array}$ \\
\hline 1905 & Gasztrin & $\begin{array}{l}\text { Antralis G-sejt } \\
(1964)\end{array}$ & $\begin{array}{l}\text { Fali sejtek (1982), colonepithel- } \\
\text { sejt, pancreasacinus-sejt (trofikus } \\
\text { hatás) }\end{array}$ & $\begin{array}{l}\text { 17. kromoszóma } \\
\text { (1986) }\end{array}$ & $\begin{array}{l}\text { Pentagasztrinteszt (1965); antigasztrinte- } \\
\text { rápia (proglumid) (1968); G17 mérése } \\
\text { (GastroPanel) }\end{array}$ \\
\hline 1928 & Kolecisztokinin & Vékonybél-I-sejt & $\begin{array}{l}\text { Duodenum, jejunum, ileum, } \\
\text { colon, pancreas }\left(\mathrm{CCK}_{1}\right)(1992) \\
\text { Gyomor, agykéreg, vagus, } \\
\text { hipofízis, pajzsmirigy, vese, here } \\
\left(\mathrm{CCK}_{2}\right)(1999)\end{array}$ & $\begin{array}{l}\mathrm{CCK}_{1} \mathrm{RG}: 4 . \\
\mathrm{CCK}_{2} \mathrm{RG}: 11 . \\
\text { kromoszóma }\end{array}$ & $\begin{array}{l}\text { CCK-teszt az epehólyag-motilitás és } \\
\text { pancreas exokrin szekréció vizsgálatára } \\
\text { (1973); proglumid, a CCK nemszelektív } \\
\text { antagonistája; szelektív } \mathrm{CCK}_{2} \text {-antagonis- } \\
\text { ták (tumorellenes hatás) (1986) }\end{array}$ \\
\hline 1972 & Szomatosztatin & $\begin{array}{l}\text { Antralis D-sejt } \\
(1980), \text { pancreas }\end{array}$ & $\begin{array}{l}S_{1-5} \text {-receptorok, fali sejt, plexus } \\
\text { myentericus neuron, pajzsmirigy }\end{array}$ & $\begin{array}{l}\mathrm{S}_{1} \mathrm{RG}: 14 . \\
\mathrm{S}_{2} \mathrm{RG}: 17 . \\
\mathrm{S}_{3} \mathrm{RG}: 23 . \\
\mathrm{S}_{4} \mathrm{RG}: 20 . \\
\mathrm{S}_{5} \mathrm{RG}: 16 . \\
\text { kromoszóma }\end{array}$ & $\begin{array}{l}\text { Szomatosztatinreceptor izotópos } \\
\text { kimutatása (1989); endokrin daganatok } \\
\text { kezelése jelzett és nem jelzett szomato- } \\
\text { sztatinanalógokkal }\end{array}$ \\
\hline 1980 & Ghrelin & $\begin{array}{l}\text { Gyomor P/Dl } \\
\text { sejt }\end{array}$ & $\begin{array}{l}\text { Hipofízis, parietalis sejtek, } \\
\text { adipocyták }\end{array}$ & 3. kromoszóma & $\begin{array}{l}\text { Gastroparesis kezelése ghrelinreceptor- } \\
\text { antagonistákkal (2014) }\end{array}$ \\
\hline
\end{tabular}

CCK = kolecisztokinin; CCKRG = kolecisztokininreceptor-gén; SRG = szomatosztatinreceptor-gén 
4. táblázat |A tirozin-kináz-receptor-gátlók története [13, 38]

\begin{tabular}{|c|c|c|c|}
\hline Év & Vegyület & A tirozin-kináz-receptor-gátlás jellege & Gastrointestinalis indikáció \\
\hline 1996 & Imatinib & PDGF-receptor-gátlás & GIST \\
\hline 2005 & Szorafenib & EGF-, PDGF-receptor-gátlás & HCC \\
\hline 2005 & Erlotinib & EGF-receptor-gátló & Pancreasrák \\
\hline 2006 & Szunatinib & PDGF-, VEGF-, c-Kit-receptor & GIST és neuroendokrin tumor \\
\hline 2007 & Nilotinib & BCR-ABL, PDGF & GIST \\
\hline 2009 & Pazopanib & FGF-, VEGF-, PDGF-receptor & GIST \\
\hline 2011 & Brivanib & VEGF-, FGF-receptor & $\mathrm{HCC}$ \\
\hline 2012 & Regorafenib & VEGF-receptor & Metasztatikus CRC, GIST \\
\hline 2013 & Linifanib & VEGF-, PDGF-receptor & HCC \\
\hline 2015 & Apatinib & $\mathrm{VEGF}_{2}$-receptor & Gyomorrák \\
\hline 2016 & Tivatinib & MET-receptor & Előrehaladott HCC \\
\hline 2016 & Levatinib & VEGF $_{1,2^{-}}$, PDGF-, EGF-receptor & HCC, pancreasrák \\
\hline 2018 & Anlotinib & VEGF $_{2^{-}}$, PDGF-receptor-gátló & CRC, HCC, gyomorrák, nyelőcsőlaphámrák \\
\hline
\end{tabular}

$\mathrm{BCR}-\mathrm{ABL}=$ a Philadelphia-kromoszóma-transzlokáció jele; $\mathrm{CRC}=$ colorectalis carcinoma; EGF = epidermalis növekedési faktor, FGF = fibroblastnövekedési faktor; GIST = gastrointestinalis stromalis tumor; HCC = hepatocellularis carcinoma; MET = hepatocytanövekedési faktor; PDGF = thrombocytaeredetű növekedési faktor, VEGF = vascularis endothelialis növekedési faktor-1-3

funkciója módosul, megvalósítva a jelátvitelt. Az emberi genom 90 tirozin-kináz-gént tartalmaz, ezek 58 enzimet kódolnak. A tirozin-kináz-receptorok nagy affinitással rendelkeznek a növekedési faktorokkal, citokinekkel és hormonokkal szemben. Az ellenük kifejlesztett kis molekulájú vegyületek és monoklonális antitestek a mai, egyénre szabott kemoterápia részei [38].

A tirozin-kináz-gátlók fejlesztése a Philadelphia-kromoszóma felfedezésével kezdődött: 1973-ban a chicagói egyetemen kimutatták, hogy a 22. kromoszómának egy darabja a 9-esre transzlokálódott, ahol fúziós gént alkot; ennek termékét az amerikai Cambridge Egyetemen David Baltimore (1938) azonosította, kimutatva, hogy egy tirozin-kináz: ekkor már 1975-ben Nobel-díjat kapott a reverz transzkriptáz felfedezéséért. A gyógyszeripar érdeklődése csak az 1990-es években kezdődött, amikor a Ciba-Geigy cég kifejlesztette az imatinibet, amely 1996ban vált gyógyszerré, és hatékonynak bizonyult a stromalis daganatok kezelésében: a fóbb vegyületeket időrendi sorrendben a 4. táblázatban ismertetjük [16, 38].

\section{Toll-szerü receptorok (toll-like receptor - TLR)}

A TLR-ok egy fehérjecsaládot képviselnek, amelyek a sejthártyában helyezkednek el, és katalitikus aktivitásuk nincs; tulajdonképpen az immunrendszer őrszemei. Központi szerepet játszanak a veleszületett immunitásban. A toll német szó, jelentése „nagyon jó, nagyszerü”, de van „klassz, féktelen, kerge, orült” jelentése is. A kifejezést Christiane Nüsslein-Volhard (1942) német genetikus használta először, amikor 1985-ben a Drosophila melanogaster egyik, mutációkat okozó, receptor jellegú géntermékét felfedezte (Nobel-díj: 1995). A 'toll-like' a toll-receptor emberi homológját jelöli. A kifejezés elterjedt az angol nyelvben, magyar fordítása nincs.

A TLR története több mint 100 évre vezethető vissza, amikor Richard Friedrich Johannes Pfeiffer (1858-1945) lengyel bakteriológus - Robert Koch (1843-1910) tanítványa - leírta, hogy a Gram-negatív baktériumok endotoxint termelnek, amely állatokban szeptikus sokkot okoz. Az endotoxin lipopoliszaharidszerkezetét tisztázták, és kiderült, hogy a baktériumok falának összetevője - de csak évtizedek múlva fedezték fel, hogy hatását receptorok révén fejti ki $[3,16]$.

Elsőként Jules A. Hoffmann (1941), a strassburgi egyetem biológusa és munkatársa mutatta ki, hogy az ecetlégy veleszületett immunitással rendelkezik gombás fertőzések ellen. Utóbb 8 gént azonosítottak a Drosophila genomjából, amelyek TLR-okat kódolnak [39]. Bruce Alan Beutler (1957) amerikai immunológus és genetikus, valamint munkatársai 1998-ban mutatták ki, hogy a $\mathrm{TLR}_{4}$ az emlősök sejthártyáján a lipopoliszaharidreceptor-komplex része. Kutatásaikért Hoffmann és Bruce 2011-ben orvosi Nobel-díjat kaptak a veleszületett immunitás folyamatának tisztázásáért [40].

Ez idáig 14 TLR-t írtak le, 9 emberben is előfordul: ezek közül a $\operatorname{TLR}_{1,2,4,5,6}$ a sejthártyában, a $\operatorname{TLR}_{3,4,7,9}$ intracellularisan helyezkedik el. A TLR-okat elöször 2000-ben mutatta ki bostoni munkacsoport emberi tenyésztett vastagbélrák- és egérvesecarcinoma-sejteken [41]. Gyulladásos bélbetegségben e receptoroknak differenciált szerepük van: míg a $\operatorname{TLR}_{1,3,4,5,6,7,9}$ gyulladásgátló hatással bír, a TLR ${ }_{2,4,6,8}$ a bélnyálkahártya gyulladását segíti elő: a különböző kísérleti modelleken egymással ellentétes hatásokat mutattak ki [42]. A TLRagonisták és -antagonisták jelenleg állnak klinikai vizsgá- 
lat alatt: hatásosságukról még korai nyilatkozni. Hazai közleményben hangsúlyozták, hogy a TLR-oknak szerepük lehet a colitis ulcerosában megjelenő colorectalis daganatokban, de rendelkeznek antitumoralis hatásokkal is [43].

A májban a TLR-ok megtalálhatók, a hepatocytákon, a Kupffer-, sinusoidalis endothel- és dendritikus sejteken, valamint a biliaris epithelsejteken: a $\operatorname{TLR}_{2,3,4,5,9}$ mindezeken differenciáltan expresszálódik, és szerepük van a nem alkoholos steatohepatitisben, az alkoholos májbetegségben, a hepatitis B- és C-vírus-fertőzésben, a hepatocellularis carcinomában, az autoimmun májbetegségekben, a transzplantáció utáni szervkilökődésben és a részleges májreszekció utáni regenerációban [44, 45].

Összefoglalva, az élő szervezetekben az élettani folyamatokat a sejthártyán elhelyezkedő jelátvivők közvetítik. A receptor fogalma a XIX-XX. század fordulóján alakult ki. A kifejezést először 1910-ben alkalmazták biológiailag aktív molekulákra, amelyek a sejtfelületen helyezkednek el. A kutatások iránya a ligandok azonosítása felől haladt a sejthártyán elhelyezkedő receptorok felé, ezt követte a receptor szerkezetének tisztázása, az agonista és antagonista vegyületek szintézise, a receptorokat szabályozó gének azonosítása és a terápiás alkalmazások: az egyes időszakok között gyakran több évtized telt el. A téma fontosságát jelzi, hogy majdnem minden receptor felfedezését Nobel-díjjal ismerték el.

\section{Köszönetnyilvánítás}

A szövegszerkesztésben nyújtott segítségéért Józan Jolánnak jár köszönet.

\section{Irodalom}

[1] Prüll CR, Maehle AH, Halliwell RH. A short history of the drug receptor concept. Palgrave Macmillan, Basingstoke-New York, NY, 2008.

[2] Stedman, TL. Stedmans's Medical Dictionary. Williams \& Wilkins, Baltimore, MD, 25th edn., 1989; p. 1327.

[3] Sebastian A. A dictionary of the history of medicine. Parthenon Publishing Group, New York, NY-London, 1999.

[4] Rang HP. The receptor concept: pharmacology's big idea. Br J Pharmacol. 2006; 147(Suppl 1): S9-S16.

[5] Langley JN. Observations on the physiological action of extracts of the supra-renal bodies. J Physiol. 1901; 27: 237-256.

[6] Ehrlich P, Sachs H. Ueber den Mechanismus der Amboceptorenwirkung. Berl Klin Med Wchschr. 1902; 21: 492-496.

[7] Clark AJ. The antagonism of acetyl choline by atropine. J Physiol. 1926; 61: 547-556.

[8] de Jong LA, Uges DR, Franke JP, et al. Receptor-ligand binding assays: technologies and applications. J Chromatogr B Analyt Technol Biomed Life Sci. 2005; 829: 1-25.

[9] Leövey A, Bakó G, Nagy E. Theoretical and clinical significance of hormone receptors. [A hormonreceptorok elméleti és klinikai jelentősége.] Orv Hetil. 1985; 126: 3007-3010. [Hungarian]

[10] Miheller P, Műzes Gy, Galamb O, et al. Molecular biology background of inflammatory bowel disease. [Gyulladásos bélbetegségek molekuláris biológiai háttere.] Orv Hetil. 2006; 147: 1395-1403. [Hungarian]
[11] Petrányi Á, Bodoky G. Drugs for the treatment of neuroendocrine tumours. [Neuroendokrin daganatok gyógyszeres kezelése.] Orv Hetil 2011; 152: 379-391. [Hungarian]

[12] Reismann P. Study of the toll-like receptor 4 gene polymorphisms in diseases presenting with subclinical and chronic inflammation. [A Toll-like receptor-4-polimorfizmus vizsgálata szubklinikus és krónikus gyulladással járó betegségekben.] Orv Hetil. 2011; 152: 1855-1858. [Hungarian]

[13] Kirschner Gy, Balla B, Kósa J, et al. Literature review and presentation of our own research results regarding the effects on bone of tyrosine kinase inhibitors imatinib and nilotinib used in the treatment of oncohematological diseases. [Az onkohematológiai betegségek kezelésében használt tirozinkináz-gátló imatinib és nilotinib csonthatásainak irodalmi áttekintése és a saját kutatási eredmények bemutatása.] Orv Hetil. 2016; 157: 1429-1437. [Hungarian]

[14] Jakab L. Oligo- and polysacharides, proteoglycans. [Oligo- és poliszaharidok, proteoglikánok.] Orv Hetil. 2018; 159: 620627. [Hungarian]

[15] Buzás GyM. Pharmacology. In: History of peptic ulcer disease. [Farmakológia. In: A peptikus fekélybetegség története.] Akadémiai Kiadó, Budapest; 2012; pp. 448-486. [Hungarian]

[16] Sneader W. Drug discovery. A history. John Wiley \& Sons Ltd, Chichester, 2015.

[17] Hetényi G. Current problems of peptic ulcer disease. [A fekélybetegség időszerű kérdései.] Akadémiai Kiadó, Budapest, 1954; pp. 138-139. [Hungarian]

[18] Black JW, Duncan WA, Durant JC, et al. Definition and antagonism of histamine $\mathrm{H}_{2}$-receptors. Nature 1972; 236: 385-390.

[19] Tulassay Zs, Döbrönte Z, Farkas I, et al. Ebrotidine versus ranitidine for healing and prevention of relapse of duodenal ulcer. A multicentre, double blind parallel, randomized, controll study. Arzneimittelforschung 1997; 47: 551-556.

[20] Takenaka R, Okada H, Kawano A, et al. Randomized study of lafutidine vs lansoprazole in patients with mild gastroesophageal reflux disease. World J Gastroenterol. 2016; 22: 5430-5435.

[21] Kiss R, Keserü GM. Structure-based discovery and binding site analysis of histamine-receptor ligands. Expert Opin Drug Discov. 2016; 11: 1165-1185

[22] Tárnok F, Jávor T, Mózsik Gy, et al. Drug combinations in peptic ulcer therapy. In: Szabó S, Mózsik Gy. (eds.) New pharmacology of ulcer disease. Elsevier, New York, NY-Amsterdam-London, 1986; pp. 78-91.

[23] Schwartz JC. The histamine $\mathrm{H}_{3}$ receptor: from discovery to clinical trials with pitolisant. Br J Pharmacol. 2011; 163: 713-721.

[24] Thurmond RL, Venable J, Savall B, et al. Clinical development of histamine $\mathrm{H}_{4}$ receptor antagonists. Hand Exp Pharmacol. 2017; 241: 301-320.

[25] Szabó S. Experimental basis for a role for sulfhydryls and dopamine in ulcerogenesis: a primer for cytoprotection-organoprotection. Klin Wochenschr. 1986; 64(Suppl 7): 116-122.

[26] Tolstanova G, Deng X, Ahluwalia A, et al. Role of dopamine and $\mathrm{D}_{2}$ dopamine receptor in the pathogenesis of inflammatory bowel disease. Dig Dis Sci. 2015; 60: 2963-2975.

[27] Rapport MM, Green AA, Page IH. Serum vasoconstrictor serotonin, isolation and characterization. J Biol Chem. 1948; 176: 1243-1251.

[28] Gaddum JH, Picarelli ZP. Two kinds of tryptamine receptors. Br J Pharmacol Chemother. 1957; 12: 323-328.

[29] Berger M, Gray JA, Roth BL. The expanded biology of serotonin. Annu Rev Med. 2009; 60: 355-366.

[30] Rehfeld JF. A centenary of gastrointestinal endocrinology. Horm Metab Res. 2004; 356: 735-741.

[31] Gregory RA. The gastrointestinal hormones: an historical review. In: Chen TS, Chen PS. (eds.) The history of gastroenterology. Parthenon Publishing Group, New York, NY-Oxford, 1995; pp. 61-90. 
[32] Levine R, Krenning EP. Clinical history of the theranostic radionuclide approach to neuroendocrine tumors and other types of cancer: Historical review based on an interview of Eric P. Krenning by Rachel Levine. J Nucl Med. 2017; 58(Suppl 2): 3S-9S.

[33] Rehfeld JF. Cholecystokinin - from local gut hormone to ubiquitous messenger. Front Endocrinol 2017; 8: 47. Doi: 10.3389/ fendo.2017.00047. eCollection 2017.

[34] Herszényi L, Mihály E, Tulassay Zs. Somatostatin and gastrointestinal tract. Clinical experiences. [A szomatosztatin és az emésztőrendszer. Klinikai tapasztalatok.] Orv Hetil. 2013; 154: 1535-1540. [Hungarian]

[35] Kojima M, Hosoda H, Date Y, et al. Ghrelin is a growth-hormone-releasing acylated peptide from stomach. Nature 1999; 402: 656-660.

[36] Balázs L. History of chemisty. Vols. I-II. [A kémia története. III. kötet.] Nemzeti Tankönyvkiadó, Budapest, 1996.

[37] Krebs EG. Historical perspectives on protein phophorylation and classification system for protein kinases. Philos Trans R Soc Lond B Biol Sci. 1983; 302: 3-11.

[38] Kazlauskas A. Receptor tyrosine kinases and their targets. Curr Opin Genet Dev. 1994; 4: 5-14

[39] Imler JL, Tauszig S, Jouanguy E, et al. LPS-induced immune response in Drosophila. J Endotoxin Res. 2000; 6: 459-462.

[40] Poltorak A, Ricciardi-Castagnoli P, Citterio S, et al. Physical contact between lipopolysaccharide and toll-like receptor 4 revealed by genetic complementation. Proc Natl Acad Sci U S A. 2000; 97: 2163-2167.

[41] Cario E, Rosenberg IM, Brandwein SL, et al. Lipopolysaccharide activates distinct signaling pathways in intestinal epithelial cell lines expressing toll-like receptors. J Immunol. 2000; 164: 966972.

[42] Lu Y, Li X, Liu S, et al. Toll-like receptors and inflammatory bowel disease. Front Immunol. 2018; 9: 72. Doi: 10.3389/ fimmu.2018.00072. eCollection 2018.

[43] Sipos F, Füri I, Constantinovits M, et al. Contribution of TLR signaling to the pathogenesis of colitis-associated cancer in inflammatory bowel disease. World J Gastroenterol. 2014; 20: 12713-12721.

[44] Kiziltas S. Toll-like receptors in pathophysiology of liver diseases. World J Hepatol. 2016; 8: 1354-1369.

[45] Yuan F, Zhang W, Mu D, et al. Kupffer cells in immune activation and tolerance toward $\mathrm{HBV} / \mathrm{HCV}$ infection. Adv Clin Exp Med. 2017; 26: 739-745.

(Buzás György Miklós dr., Budapest, Mester u. 45., 1095 e-mail:drbgym@gmail.com)

\section{ÁLLÁSAJÁNLAT}

A Gottsegen György Országos Kardiológiai Intézet (1096 Budapest, Haller u. 29.) pályázatot hirdet aneszteziológus és intenzív terápiás szakorvos munkakörbe, határozatlan idejü közalkalmazotti kinevezéssel, személyre szabott, kiemelt bérezéssel.

\section{Feladatai:}

Altatás a Szívsebészeti/Érsebészeti mütökben, Haemodinamikai Laborban, Elektrofiziológiai és Pacemaker Osztály mütőiben és az ambulancián. Osztályos munka végzése a felnőtt szív- és érsebészeti Intenziv Osztályon. Részvétel az Aneszteziológiai és Intenzív Osztály ügyeleteiben és behívásos ügyeleteiben. Részvétel az aneszteziológiai ambulancia munkájában, preoperatív betegelőkészitésben és konzílium adása a társosztályok számára.

\section{Pályázati feltételek:}

- orvosi egyetem

- aneszteziológia és intenzív terápia szakvizsga vagy általános orvos szakvizsga előtt

- érsebészeti anesztéziában való jártasság

- büntetlen előélet, egészségügyi alkalmasság

Előnyt jelent:

- szívsebészeti anesztéziában való jártasság

- angol nyelvtudás

A Pályázat benyújtásának módja és helye:

Elektronikus úton: vali.nemeth@kardio.hu

Postai úton: Németh Valéria humánpolitikai igazgató részére, „Aneszteziológus és intenzív terápiás szakorvos pályázat” megjelöléssel, az alábbi címre: 1096 Budapest Haller u. 29. 